\title{
ANALYSIS OF FACTORS THAT AFFECT STUDENTS AND COLLEGE STUDENT ON THEIR DECISION TO BUY PRODUCTS THROUGH ONLINE APPLICATIONS IN SEMARANG
}

\author{
Edy Suryawardana ${ }^{3}$ \\ Edy Mulyantomo \\ Tri Endang Yani \\ Faculty of Economics, University of Semarang
}

\begin{abstract}
This study analyzes the factors that affect students and college students in online purchasing decisions in Semarang. The growth of various online companies (shops) today is like mushrooms that grow in the rainy season. The business of buying and selling goods and services online provides many benefits for consumers and online shop owners. But along with the growth of online trading, complaints from consumers also increased.

This study aims to determine and analyze the influence of perceived prices, promotions and reputation on online purchasing decisions. This study uses validity and reliability test methods, classic assumption and multiple linear regression tests such as t test, $\mathrm{f}$ test and multiple correlation test and determination (data were processed using SPSS 24.0 software).

The results obtained from this study are perceptions of price, promotion and reputation variable affect online purchasing decisions.

Keywords: reputation, price perception, promotion, purchasing decisions, online trade

\section{INTRODUCTION}

There are many types of online buying and selling services, both from within the country and abroad such as alibaba.com, bukalapak.com, inkuiri.com, OLX.com, jakartanotebook.com and many more. The service providers provide convenience and easy transaction using the application in terms of offering, payment and distribution of goods.
\end{abstract}

Figure1.

Projections for online buying and selling in Indonesia in 2016 - 2022

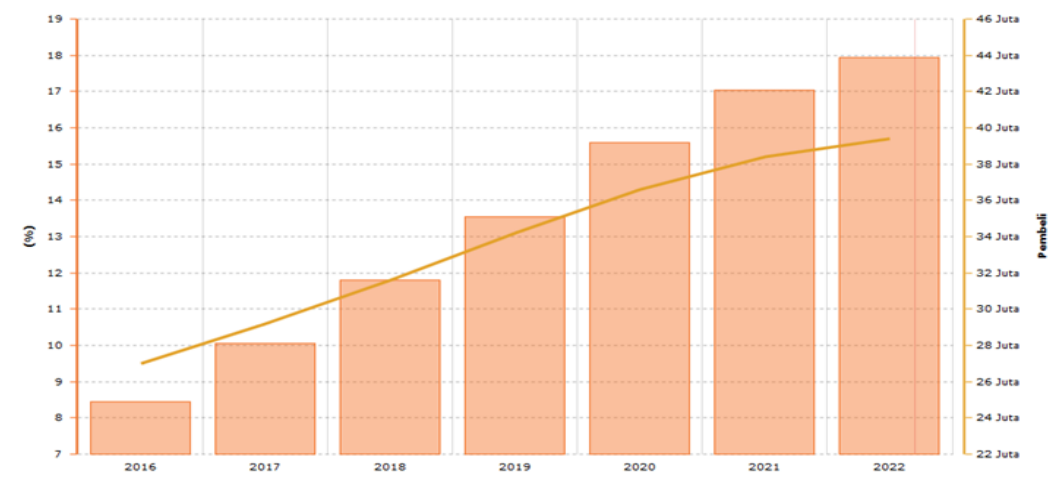

Source: BKPM Republic of Indonesia, 2018

3edysurya6@usm.ac.id; Faculty of Economics, University of Semarang 
Figure 1 shows that online-based buying and selling potential in Indonesia is still open. Graph of sales transactions has increased from year to year. Starting in 2016 online buying and selling services has shown fierce competition. People who join this kind of business are getting increased.

On the other hand, complaints about online transactions also increased. Indonesian Consumers Foundation (YLKI) noted that during 2017, consumers mostly complained about their experience while doing online transaction. From 642 general complaints since JanuaryNovember 2017, YLKI received 101 (16\%) complaints from online shopping. The number of complaints related to online shopping has doubled compared to 2016. In 2016, the number of online complaints was only $8 \%$. This number is higher than consumer complaints about banks services that were previously in first place. During 2017, complaints against banks were only 83 complaints, or $13 \%$. "Currently, online shopping complaint is the highest" said Tulus Abadi, YLKI chairman (in Bayu, 2018). Furthermore, it was informed that consumers often complained about the slow response of complaints (44\%), receipt of goods $(36 \%)$, adverse system (20\%), no refund (17\%), suspected fraud (11\%), items purchased did not appropriate $(9 \%)$, suspected cyber crime $(8 \%)$. There are also complaints about product defects $(6 \%)$, services $(2 \%)$, prices (1\%), information (1\%), and late receipt of goods $(1 \%)$. In Indonesia, students and college students are one of the largest segments that are ready to become sales targets for online buying and selling providers. The items offered are targeting the millennial generation. The fact that these generation is still looking for identity is the reason that they are become potential buyers in Indonesia. Students and college students often want good items at affordable prices. The consumerism lifestyle that engulfed the world contributed to the lifestyle of students and college students in Indonesia.

The questions that come up from this study are; how does price perception affect the decision to buy online? How does promotion affect the decision to buy online? And how does reputation affect the decision to buy online? While the purpose of this study was to know and to analyze the effect of price perceptions on online purchase decisions, to know and to analyze the effect of promotion on online purchase decisions and to know and to analyze the effect of reputation on online purchase decisions.

\section{LITERATURE REVIEW AND HYPOTHESIS DEVELOPMENT}

Purchase decisions that were made by consumers are determined through many considerations. Choosing the goods or services to be purchased requires information related to products or services. Purchase decision errors will harm the consumer.

Price is one of the factors that affect the interest of consumers to get the goods or services. The price perception offered by the seller is often being considered by consumers to determine what they choose.

Consumer interest in buying products and services is often influenced by promotions from the sellers. The power of promotion can make the consumer to buy the product because the consumers is trying to get the benefits from the promotion.

While choosing the product, the consumers often see the reputation of the store (vendor) that sells the product. The better reputation of the store or vendor, the more it will be chosen by consumers to buy their products.

Consumer's price perception has an important influence to determine the decision to buy goods and services. According to Harwani and Pradita (2017) in their study, price perception affects purchase decisions. Ruslim and Tumewu (2015) emphasized that price perceptions affect consumer purchase decisions. Therefore:

H1: There is an Influence of Price Perception on Purchase Decisions. 
A good promotion will have positive effect on the company and consumers. Study conducted by Brata et al. (2017) shows that promotion affect purchase decisions. Furthermore, Shrestha (2015) confirmed that sales promotions have a significant effect on purchase decisions. Therefore:

H2: There is an Influence of Promotion on Purchase Decisions.

The reputation of online stores is one of the references for consumers to buy goods and services. Jung and Seock (2016) in their study said that corporate reputation affects purchase decisions. Similarly, Ong et al. (2015) emphasize that the company's reputation significantly affects consumer purchase decisions. Therefore:

H3: There is a Reputation Effect on Purchase Decisions

Figure 2. Empirical Thinking Framework

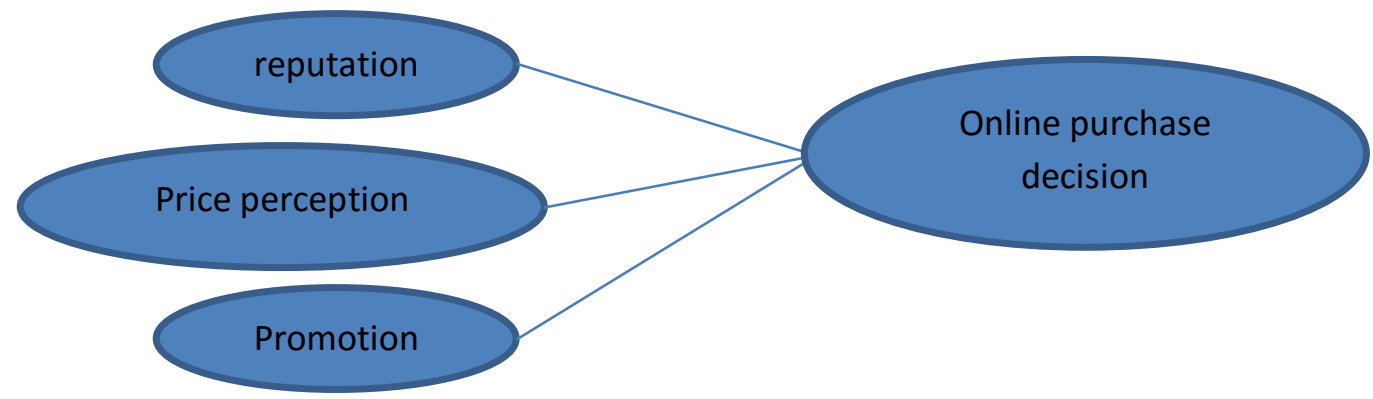

\section{METHOD, DATA AND ANALYSIS}

\section{Operational Definition}

According to Sobur, (2010: 445) Perception is a vision that is how someone sees something; perception also means as view, it how someone perceives or interpret something. While price is the amount of money charged for a product or service. (Kotler and Armstrong, 2001: 339). Price perception can be measured from: price level, price discount, and payment terms. Promotion is one of marketing strategy from the company to notify, remind, and persuade consumers about the products of the company (Saladin, 2003), the indicators used for promotional variables are (Miles and Covin: 2000): advertising, sales promotion and direct marketing via media application.

Reputation is an award obtained by the company because of the advantages that exist in the company, such as the ability possessed by the company, so that the company will continue to develop itself to create new things for fulfill consumer needs (Herbig et al., 1994). The indicators used for reputation variables are: competent, credible and good name.

Purchase decisions are the activities of individuals who are directly involved in making decisions to purchase products offered by sellers. The indicators used for purchasing decision variables are (Howard and Shay in Dharmesta, 1998): how long the consumers decide due to internal and external factors, make considerations by collecting data / information and quickly decide.

\section{Population and Samples}

The populations in this study are all consumers consist of students and college students who buy goods or services online in Semarang where the exact number cannot be calculated. The sampling method uses is Purposive Sampling, the sample criteria in this study are consumers 
who are at least 17 years old as students or college students and where they buy products online and use online services. In this study the number of samples taken was 97 students or college students who were expected to be equal to the number of respondents.

\section{Data and Analysis}

The types of data in this study are primary data and secondary data. Data collection methods are Observation, Questioner, Interview, and Literature Study.

This study uses SPSS program version 24.00. Validity test results show that all items of questions / indicators of Price Perception variables (X1), Promotion (X2), Reputation (X3), and Purchase Decisions (Y) are declared valid because of the correlation between the results of respondents' answers to each question / indicator item with the total score can get significant results, namely the value of $r_{\text {count }}>r_{\text {table. }}$.

Reliability test results show that the value of Cronbach's Alpha of all variables above 0.60, so it can be concluded that the price perception variable (X1), Promotion variable (X2), Reputation variable (X3), and Purchase Decision (Y) are declared reliable or reliable / reliable, which means if the data is used on different objects study, at different times it will give the same results as the results obtained in this study. It also shows that the value of $p_{\text {value }}$ (Asymp.Sig.) Of the residual regression model is $>0.05$. Therefore it can be concluded that the data used in this study is normally distributed.

Based on the results of the multicollinearity test the regression model shows that between the Price Perception variables (X1), Promotion variables (X2), Reputation variables (X3), and Purchase Decisions (Y) all do not occurs multicollinearity, because the value of tolerance of each independent variable is above 0,1 and the VIF value of each independent variable is below 10.

Based on the results of the analysis using SPSS program (Ghozali, 2005), the regression results obtained between the independent variables on the dependent variable in table 1 in the appendix.

The t-test results show that all independent variables have a positive and significant effect on the dependent variable, because the value of $t$ count $>$ from $t$ table.

\section{DISCUSSION}

Hypothesis 1 states that "price perception has a positive effect on purchase decisions." Regression testing results show $\left[\mathrm{p}_{\text {value }}(\right.$ Sig. $\left.\left.)=0.004\right)\right]<0.025$ and $\left.\left(\mathrm{t}_{\text {count }}=2.201\right)\right\rangle\left(\mathrm{t}_{\text {table }}=\right.$ 1.960), the t test results is "significant" and "positive (the sign at $t$ and beta coefficient is positive)", so $\mathrm{H}_{\mathrm{o}}$ is rejected and $\mathrm{H}_{\mathrm{a}}$ is accepted, which means the perception of price (X1) has a positive and significant effect on purchase decisions $(\mathrm{Y})$ on online purchases by students and college student. "Significant" implies that the perception of price does have a significant influence on purchase decisions, so it can be concluded that the changes that occur in purchase decisions are influenced / determined by changes in prices perception, but do not apply otherwise. While the relationship "Positive" means that the changes that occur in the purchase decision goes in line with changes in price perception. If the price perception variable increases, it will automatically be followed by an increase in the purchase decision variable, and vice versa.

Hypothesis 2 states that "company promotion has a positive effect on purchase decisions." Regression test results show [ $\mathrm{p}_{\text {value }}($ Sig. $\left.\left.)=0.001\right)\right]<0.025$ and $\left.\left(\mathrm{t}_{\text {count }}=2.532\right)\right\rangle\left(\mathrm{t}_{\text {table }}=1.960\right)$, then the t-test results is "significant" and "positive (the sign on $\mathrm{t}$ and beta coefficient is positive)", so $\mathrm{H}_{\mathrm{o}}$ is rejected and $\mathrm{H}_{\mathrm{a}}$ is accepted, which means promotion (X2) has a positive and significant effect on purchase decisions (Y) on online purchases by students and college students. "Significant" implies that companies promotion does have a significant influence on purchase decisions, so it can be concluded that changes that occur in purchase decisions are 
influenced / determined by changes in companies promotion, but do not apply otherwise. While the relationship "Positive" means that the changes that occur in the purchase decision goes in line with the changes of company promotion. If the companies' promotion variable has increased, it will automatically be followed by an increase in the purchase decision variable, and vice versa.

Hypothesis 3 states that "reputation has a positive effect on purchase decisions." The regression test results show $\left.\left[p_{\text {value }}(\operatorname{Sig})=0,000.\right)\right]<0.025$ and $\left.\left(t_{\text {count }}=3.101\right)\right\rangle\left(t_{\text {table }}=1.960\right)$, the results of the t-test are "Significant" and "positive (signs at $t$ and beta coefficients are positive)", so $\mathrm{H}_{\mathrm{o}}$ is rejected and $\mathrm{H}_{\mathrm{a}}$ is accepted, which means companies reputation (X3) has a positive and significant effect on purchase decisions (Y) on online purchases by students and college students. "Significant" implies that reputation does have a significant influence on purchasing decisions, so it can be concluded that the changes that occur in purchase decisions are influenced / determined by changes in reputation, but do not apply otherwise. While the relationship "Positive" means that the changes that occur in purchase decisions go in line with changes in reputation. If the reputation variable increases, it will automatically be followed by an increase in the purchase decision variable, and vice versa.

\section{CONSLUSION}

Based on the results of data analysis that has been carried out on all data obtained, it can be concluded that, there is a positive and significant influence of the price perception variable (X1) on purchase decisions (Y) is accepted; There is a positive and significant effect of the company promotion variable $(\mathrm{X} 2)$ on purchase decisions $(\mathrm{Y})$ is accepted; There is a positive and significant influence of the reputation variable (X3) on purchase decisions (Y) is accepted.

The findings of the implementation of this study can be explored by several implications for the existing theory. Among other things, the company's reputation can be better or vice versa. According to Lau and Lee (1999), they say that company's reputation as one of the most important factors of company characteristics that can shape customer trust to the brand. Therefore a good reputation can be created by increasing consumer trust to the company.

\section{MANAGERIAL IMPLICATION}

Based on the result of this study, the researcher suggested that affordability of prices by students and college students. It is known that there are still many segments that do not have their own income; the reputation of the company should be well maintained. The researcher also suggested that online companies should maintain the reputation. Better reputation means the consumers trust the online companies more; it is necessary to improve the quality of services by practicing: the availability of qualify goods and services and providing guarantees if online companies provide services that are not optimal to their customers.

The result of this study is unsatisfactory due to the limitations of the researchers, including the sample of this study only come from students and college students in Semarang who do not have their own income. It should be conducted at the city or other region by adding professional segments (employees).

There is a possibility to develop this study further; therefore the further study is expected in future. The researchers may be able to use the variables that were used in this study by adding several variables or even making variable changes which according to variables which mostly affect customer loyalty to use online services. 


\section{DAFTAR PUSTAKA}

Alex, Sobur. (2010). Psikologi Umum. Bandung: Pustaka Setia.

Anderson, E. W., \& Sullivan, M. W. (1999). The antecedents and consequences of customer satisfaction for firms. Mark. Sci., 12, 125-143.

Anderson, H., \& Jacobsen P. N. (2000). Creating Loyalty: Its Strategic Importance in Your Customer Strategy. In S. A. Brown (ed.), Customer Relationship Management (pp. 55-67).

Brata, Barun, Hadi. Silvana, Husani. Hapzi, Ali. 2017. The Influence of Quality Product, Price, Promotion, and Location to Product Purchase on NitchiAt PT. Jaya Swarasa Agung in Central Jakarta. Saudi ournal of Business and Manajement Studies, Vol.2, ISSN.2415-6663, ISSN. 2415- 6671, Hal: 433-445.

Basu Swastha Dharmesta, 1998, “Teknologi Informasi Dalam Pemasaran: Implikasi Dalam Pendidikan Pemasaran", Jurnal Ekonomi dan Bisnis Indonesia, XIII (3)

Dinawan, M, Rhendria. 2010. Analisis Faktor-Faktor yang Mempengaruhi Keputusan Pembelian (studi kasus pada konsumen yamaha mio PT harpindo jaya semarang). Tesis. Semarang: Universitas Diponegoro.

Drucker, Peter F. "Innovation And Entrepreneurship: Practice And Principle, New York:Prenential Library, 1985

Fandy Tjiptono,. 2000. Prinsip \& Dinamika Pemasaran. Edisi Pertama, Learning : Yogyakarta

Gatot Yulianto dan Purwanto Waluyo, 2004, "Pengaruh Keefektifan Komunikasi, Kualitas Teknikal, Kualitas Fungsional dan Kepercayaan Pada Komitmen Keterhubungan Bandara Ahmad Yani Semarang", Telaah Manajemen, Vol.1 Edisi 3.

Gefen, D., E. Karahanna, and D.W. Straub, "Trust and TAM in Online Shopping: An Integrated Model," MIS Quarterly, Vol. 27, No. 1:51-90, 2003. Gibson, James L”Organization"New York; Business Publication, Inc, 1985

Ghozali, Imam. 2000. Aplikasi Analisis Multivariate dengan SPSS. Semarang: Universitas Diponegoro.

-----, 2005. Aplikasi Analisis Multivariate dengan SPSS. Semarang: Universitas Diponegoro. -----, 2006. Aplikasi Analisis Multivariate dengan SPSS. Semarang: Universitas Diponegoro.

Gunarsa Singgih D., "Psikologi Praktis : Anak, Remaja Dan Keluarga", Jakarta, BPK Gunnung Mulia, 1991

Gunawan ( 2006 ) Pengaruh Rasio Keuangan Terhadap Pertumbuhan Laba Pada Perusahaan Perdagangan Di Indonesia", jurnal ilmiah dan bisnis, Vol 13, No 1

Harper, Stephen C'Starting Your Own Business, New York;Mcgraw Hill, 1991

Yuli Harwani, ShindyRamadiyaniPradita . 2017. Effect of Brand Image and Perceived Price Towards Purchase Decision in Kentucky Fried Chicken (KFC).Journal of Marketing and Consumer Research . Vol. 36.

Herbig, milewicz and Golden ( 1994 ), "Differences in Forecasting Behavior between Industrial Product Firms and Consumer Product Firms,"Journal of Business \& Industrial Marketing, Volume 9, Issue 1.

Hisrich, Tobert D, Peter Michel P, "Entrepreneurship: Starting, Developing And Managing A New Enterprise, Tokyo: Richard D. Irwin, 1992

Hoffman, D.L., Novak, T.P., Peralta, M., 1999. Building consumer trust online. Communications of the ACM 42 (4), 80 - 85.

Hurlock, Elizabeth B., Psikologi Perkembangan: Suatu Pendekatan Sepanjang Rentang Kehidupan, Jakarta, Erlangga, 1991

J. P. Meyer and Allen, N. J., (1997)," Commitment in The Workplace Theory Research and Application. Califotnia: Sage Publications.

Jarvenpaa \& Staples, 2000). The use of collaborative electronic media for information 
sharing: an exploratory study of determinants, The Journal of Strategic Information Systems 9 (2), 129-154

Jung, N. Y., \& Seock, Y. (2016). The impact of corporate reputation on brand attitude and purchase intention, Fashion and Textiles, 3(1), 1-15.

Kotler, Philip. 2001. Manajemen Pemasaran Indonesia. Jakarta : Salemba Empat

Kotler (1997) Marketing Management "Analysis, Planning, Implementation and Control" (9 th ed.). New Jersey: Prentice Hall

Lau, G. T. and Lee, S. H. (1999). "Consumers' trust in a brand and the link to brand loyalty". Journal of Market Focused Management. 4, pp. 341-370.

Llosa, Sylvie, Jean Louis Chandon And Chiara Onsingher, (1998), An Empirical Study Of Servqual 'S Dimensionality, The Service Industries Journal, Volume 18

Lupiyoadi, R Dan Hamdani, A. 2008. Manajemen Pemasaran Jasa. Salemba Empat. Jakarta. Nasir, Muhammad. 2003. Metode Penelitian. Cetakan Kelima. Jakarta: Ghalia Indonesia.

Maltz, S, A. (1992). Cookie and Cracker Technology,"AVI Publishing Company Inc. London Miles, Morgan P \& Jeffrey G. Covin, (2000), "Environmental Marketing : A Source of

Reputational, Competitive and Financial Advantage", Journal of Business Ethics, 23, p.299-311

Mollano, Diego"Corporate Responsibility And Entrepreneurship A Youth Insight" Washington:AIESEC Int, 1992

Nur Indriantoro, Dan Bambang Supomo. 2002. Metodologi Penelitian Bisnis. Yogyakata : BPFE

Wan-Ding Ong, Beng-Ti Tey, Siew Young Quek, Siah-Ying Tang, Dan Eng-Seng Chan, (2015), "Alginate-Based Emulsion Template Containing High Oil Loading Stabilized By Nonionic Surfactants”, volume 80, issue 1

Pappas, James L., Mark Hirschey, Ekonomi Manajerial, Jakarta, Bina Rupa Aksara, 1995

Parasuraman, A, Valerie A Zeithml, Leonard L Berry (1985), A Conceptual Model Of Service Quality And Its Implications For Future Research, Journal Of Marketing, Volume 49.

Patty,"Pengantar Psikologi Umum”, Surabaya, Usaha Nasional, 1982

Pradhita Widya Herfiana Studi Mengenai Loyalitas Pelanggan Pada Divisi Asuransi Kumpulan AJB Bumi Putera 1912 (Studi Kasus di Jawa Tengah), Jurnal Sains Pemasaran Indonesia : Vol. III, No. 3. p.289 - 308

Robbin Stephen P" Organization Behaviour"New Jersey; Prentice Hall Int, 1993.

Ruslim Dan Tumewu (2015), "Pengaruh Iklan, Persepsi Harga Dan Citra Merek Terhadap

Keputusan Pembelian Konsumen Padatelepon Genggam Asus”, Jurnal Emba, Vol.3 No.3, Sept. 2015, Hal.393-401

Saladin, Djaslim, 2003, “Intisari Pemasaran Dan Unsur-UnsurPemasaran”,Cetakan Ketiga, Bandung : Linda Karya

Selnes, Fred, 1993, "An Examination of the Effect of Product Performance on Brand

Reputation, Satisfaction and Loyalty," European Journal of Marketing 27 (9), 19-35

Bal Gopal Shrestha. 2015. The Newars of Sikkim: Reinventing Language, Culture, and Identity in the Diaspora. Kathmandu: Vajra Books.

Singarimbun, Masri, (2002), “ Manajemen Sumber Daya Manusia, " Salemba Empat, Jakarta

Sjahrir, Meramal Ekonomi Di Tengah Ketidakapastian, Jakarta, Gramedia, 1995.

Steers, Richard M, Lyman W. Porter"Motivation And Work Behaviour, Singapore:Mc Grawhill, 1991

Sugiyono. 2008. Metode Penelitian Bisnis. Cetakan Kesebelas.Alfabeta.Januari-2008. Suharsimi Arikunto,. 2006. Prosedur Penelitian Suatu Pendekatan Praktik. Jakarta : PT. Rinekacipta 
Sunaryo, Indriyati”Perilaku Organisasi” Bandung” ITB, 1992

Tjiptono, Fandy. 2008.Manajemen Jasa. Cetakan Kedua. Bayumedia Publishing. Yogyakarta

Table 1.

Results of Linear Regression Analysis

\begin{tabular}{|c|c|c|c|c|c|}
\hline \multirow[b]{2}{*}{ Model } & \multicolumn{2}{|c|}{$\begin{array}{l}\text { Unstandardized } \\
\text { Coefficients }\end{array}$} & $\begin{array}{c}\text { Standardized } \\
\text { Coefficients }\end{array}$ & \multirow[b]{2}{*}{$\mathrm{t}$} & \multirow[b]{2}{*}{ Sig. } \\
\hline & B & $\begin{array}{l}\text { Std. } \\
\text { Error }\end{array}$ & Beta & & \\
\hline $1 \quad$ (Constant) & $\begin{array}{r}3.06 \\
8\end{array}$ & 1.864 & & 2,312 & 005 \\
\hline $\begin{array}{l}\text { PRICE } \\
\text { PRECEPTION }\end{array}$ &, 157 & ,063 & , 178 & 2,201 & ,002 \\
\hline PROMOTION & , $132^{-}$ & ,077 &, 183 & 2,532 & ,001 \\
\hline $\begin{array}{l}\text { REPUTATIO } \\
\mathrm{N}\end{array}$ &, 280 & 081 & ,351 & 3.101 & ,000 \\
\hline
\end{tabular}

